\title{
A new name in southern African Justicia L. (Acanthaceae)
}

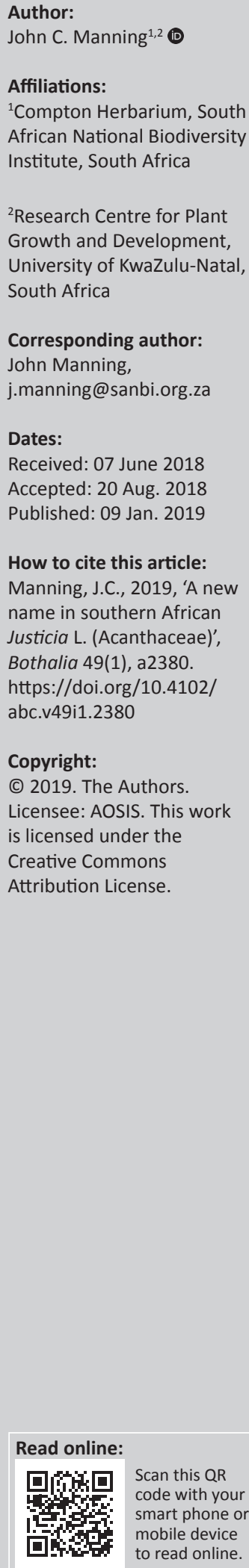

Background: Ongoing systematic studies in the African flora necessitate periodic nomenclatural adjustments and corrections.

Objectives: The objective of this study was to effect requisite nomenclatural changes.

Method: Relevant literature was consulted and type specimens were examined.

Results: One nomenclatural correction is required in Justicia L. (Acanthaceae).

Conclusion: The replacement name Justicia conferta J.C.Manning \& Goldblatt is provided for the illegitimate homonym Justicia densiflora (Hochst.) J.C.Manning \& Goldblatt, and the validity of the combination Justicia andromeda (Lindau) J.C.Manning \& Goldblatt is clarified.

\section{Introduction}

Justicia L. (Acanthaceae: Ruellieae: Justiciinae) is the largest genus of Acanthaceae, containing at a conservative estimate some $600 \mathrm{spp}$. (Graham 1988). The infrageneric classification for Justicia proposed by Graham (1988) did not include all of the southern African species, and this was subsequently corrected by Manning and Goldblatt (2014) in a synopsis of the genus for the region. As a result of an oversight, however, one nomenclatural correction is required in the combinations published by them (Manning \& Goldblatt 2014) and this is provided here.

Advances in our understanding of the phylogenetic relationships among Justicia and allied genera since the publication of Graham's (1988) classification, in particular the position of Diclipterinae as sister to the New World elements within the justicioid lineage, point to the need for a radical review of generic circumscriptions in the tribe (Kiel et al. 2017; McDade et al. 2000). This is certainly going to affect the southern African members. However, until a new, monophyletic classification is published, it is reasonable to follow the classification proposed by Graham (1988) as being the most comprehensive that is available and in order to align the taxonomy of the southern African species with that presently implemented in tropical Africa.

\section{Materials and methods}

Relevant literature was consulted. Online images of types were examined on https://plants.jstor.org/.

\section{Nomenclature}

1. Justicia andromeda (Lindau) J.C.Manning \& Goldblatt in Bothalia 44(1), Art. \#169: 4 (2014). Duvernoia andromeda Lindau in Botanische Jahrbücher 20: 42 (1894). Adhatoda andromeda (Lindau) C.B.Clarke in Flora Capensis 5, 1: 76 (1901). Type: South Africa, KwaZulu-Natal, 'Pondoland auf Triften', Oct. 1888, Bachmann 1273 (B, holo. $†$; K[000378681]-digital image!, lecto., designated here).

[Note: The combination published by Manning and Goldblatt (2014) was listed in the International Plant Names Index (http:/ /www.ipni.org/ipni; website accessed on 27 September 2018) as an invalid name, evidently on the basis that the authors had erred in their citation of the place and date of publication of the basionym, which was published in Botanischer Jahrbücher (1894) and not in Engler \& Prantl's Die natutürlichen Pflanzenfamilien (1895) as was cited. However, both Art. 41.6 Ex. 19 and 41.8c of the International Code of Nomenclature for algae, fungi, and plants (Turland et al., 2018) make it clear that errors of this kind in the citation of the basionym are to be treated as correctible and do not affect the validity of the publication of the combination.]

2. Justicia conferta J.C.Manning \& Goldblatt, nom. nov. pro. Gendarussa densiflora Hochst in Flora 28: 71 (1845). Adhatoda densiflora (Hochst.) J.C.Manning in Getliffe-Norris et al.: 490 (1985). 
Justicia densiflora (Hochst.) J.C.Manning \& Goldblatt, nom. illegit., non J. densiflora (Oerst.) V.A.Graham (1988). Type: South Africa, KwaZulu-Natal, 'in collibus prope Pieter Maritzburg' [Pietermaritzburg], Sep. 1839, Krauss 453 (K[000378678]-digital image!, lecto., designated by Manning in Getliffe-Norris, Balkwill \& Manning. (1985); BM[000931352]-digital image!, K[000378680]-digital image!, TUB[004459]-digital image!, iso.).

Adhatoda natalensis Nees: 391 (1847), nom. illeg. superfl. [based on same type as Gendarussa densiflora Hochst. (1845)]. Justicia natalensis T.Anderson: 38 (1863), nom. illeg. Type: as for Gendarussa densiflora Hochst.

[Note: The combination Justicia densiflora (Hochst.) J.C.Manning \& Goldblatt (2014) is an illegitimate later homonym (Turland et al., 2018: Art. 53) of J. densiflora (Oerst.) V.A.Graham (1988). The only later synonym for the species, Adhatoda natalensis Nees (1847), is an illegitimate superfluous name for Gendarussa densiflora Hochst., being based on the same type as that name (Turland et al., 2018: Art. 52), viz. the collection Krauss 453 from Bentham's herbarium, which is now at Kew.]

\section{Acknowledgements}

Ronell Klopper kindly drew my attention to these oversights. I thank the referees for picking up on minor errors.

\section{Competing interests}

The author declares that he has no financial or personal relationships that may have inappropriately influenced him in writing this article.

\section{References}

Anderson, T.A., 1863 ['1864'], 'An enumeration of the species of Acanthaceae from the continent of Africa and the adjacent islands', Journal of the Linnean Society, Botany 7, 13-54.

Clarke, C.B., 1901, 'XXIII. Adhatoda Nees', in W.T. Thiselton-Dyer (ed.), Flora Capensis 5(1), 75-77, Lovell Reeve \& Co., London.

Getliffe-Norris, F., Balkwill, K. \& Manning, J.C., 1985, 'New combinations and synonyms in southern African Acanthaceae', South African Journal of Botany 51, 489-490. https://doi.org/10.1016/S0254-6299(16)31628-3

Graham, V.A., 1988, 'Delimitation and infra-generic classification of Justicia (Acanthaceae)', Kew Bulletin 43, 551-624. https://doi.org/10.2307/4129957

Hochstetter, C.F., 1845, 'Pflanzen des Cap- und Natal-Landes, gesammelt und zusammengestelt von Dr. Ferdinand Krauss. Acanthaceae Juss.', Flora 28, 70-72.

Kiel, C.A., Daniel, T.F., Darbyshire, I. \& McDade, L.A., 2017, 'Unravelling relationships in the morphologically diverse and taxonomically challenging "justicioid" lineage (Acanthaceae: Justicieae)', Taxon 66, 645-674. https://doi.org/10.12705/663.8

Lindau, G., 1894 ['1895'], 'Beiträge zur Flora von Afrika IX: Acanthaceae africanae II', Botanische Jahrbücher 20, 1-76.

Manning, J.C. \& Goldblatt, P., 2014, 'Synopsis of the genus Justicia L. (Acanthaceae) in southern Africa, with eight new combinations for species of Adhatoda Miller and Monechma Hochst.', Bothalia 44(1), Art. \#169, 1-6.

McDade, L.A., Daniel, T.F., Masta, S.E. \& Riley, K.M., 2000, 'Phylogenetic relationships within the tribe Justicieae (Acanthaceae): Evidence from molecular sequences, morphology, and cytology, Annals of the Missouri Botanical Garden 87, 435-458. https://doi.org/10.2307/2666140

Nees von Esenbeck, C.G., 1847, 'Ordo CXLV. Acanthaceae', in A.P. de Candolle (ed.) Prodromus systematis naturalis regni vegetabilis $11,46-519$, Masson, Paris.

Turland, N.J., Wiersema, J.H., Barrie, F.R., Greuter, W., Hawksworth, D.L., Herendeen, P.S. et al., 2018, International Code of Nomenclature for algae, fungi, and plants (Shenzhen code) adopted by the Nineteenth International Botanical Congress Shenzhen, China, July 2017, Regnum Vegetabile 159, Koeltz Botanical Books, Glashütten. 